\title{
aderir às coisas OU sublimá-las? a escrita de gabriela ananiase matheus freire oliveira
}

\section{Rodrigo Alves do Nascimento*}

* Mestre em Literatura e Cultura Russa pela USP. Atualmente, doutorando do mesmo programa, faz pesquisa com bolsa Fapesp referente à dramaturgia de Anton Tchékhov. Email para contato: rodrigotutao@gmail.com.
Aqui, todas impricam comigo. Dizem que falo muito bem. [...] Quando fico nervosa não gosto de discutir. Prefiro escrever. Todos os dias eu escrevo. Sento no quintal e escrevo.

(Trecho de Quarto de despejo: diário de uma favelada, de Carolina Maria de Jesus)

Já diria Elias Canetti (2011) que o poeta que "exibe seus sentimentos, que infla publicamente o trivial com sua compaixão, o conspurca e destrói". Ao escavar o íntimo das vidas miseráveis e recobri-las com visão adocicada, o artista não só reduz a complexidade do desenho, como denuncia uma posição de classe. Não à toa, Jean-Claude Bernardet (2014) diria ser a miséria um grande achado temático da classe média brasileira, que a converteu em 
objeto soberano no cinema nacional contemporâneo. Mas, se não inserida dentro de um conjunto de relações mais amplo, ela se torna agenciadora de piedade e lamentação da infelicidade. Despolitizada, mais silencia que problematiza.

Não é esse, no entanto, o perigo que corre "deus ouve as mulheres", de Gabriela Nascimento Ananias. E o acerto do monólogo por ela construído reside num movimento duplo. Primeiro, não fala sobre o que não conhece. É muIher, e muito provavelmente conviveu em detalhe com a vida dura na qual está imersa sua personagem. A pena que constrói a trama não é distante nem adocicada, pelo contrário: faz fotografia consistente de um interior (físico e psicológico) que se apresenta cru e verdadeiro logo nas primeiras linhas. Está presente na receita do mingau, no seu tempo de preparação, no tempo para desfazer o estrago da comida queimada, no preço do gás, no desejo por um lençol macio sem bolinhas de pelo; está no sofrimento da mãe que sabe que a desatenção do filho não é deficiência, pelo contrário: é meninice; e por isso mesmo se recusa a aceitar o diagnóstico da professora, rápida na culpabilização do garoto. A autora não está distante das pequenas e grandes angústias da casa, que configuram um universo ao mesmo tempo tão básico e desconhecido que só pode ser apresentado de maneira convincente caso tenha sido experienciado de maneira direta. E Gabriela Ananias o apresenta por meio da palavra substantiva: pessoas, "deus" e a própria escrita são substantivos comuns. Não há maiúsculas, como não há importâncias ou espiritualidades. Adere ao que é sólido, à matéria.

Em segundo lugar, seu acerto reside na própria escolha formal. A forma monólogo concede à sua personagem voz direta e solitária, por isso mesmo mais penetrante, sem as mediações frequentes de um narrador. Ora, na tradição dos séculos XIX e XX, a voz que mediou a emergência da mulher e do pobre foi sempre marcada por uma perspectiva externa, ora objetificante, ora ex- própria condição da literatura enquanto discurso e instituição: branca, burguesa e masculina. Não à toa, só muito recentemente a experiência da condição da mulher emergiu como discurso público, como subsídio para o debate. $E$, ainda que acusada inicialmente de particularista e restritiva, revelou novas formas de problematizar o mundo e a própria narrativa, de ressignificar o corpo e as diferentes formas de subjugá-lo. Tornou-se, por isso, altamente política. Por outro lado, o teatro realista ou naturalista sempre negligenciou o monólogo, restringindo- o a momentos excepcionais de epifania, embriaguez ou sonho (SZONDI, 2001), pois a personagem que confia a si própria, em voz alta, seus próprios sentimentos, seria facilmente tida como ridícula, estranha, louca e, por isso mesmo, inverossímil. Nesse sentido, o monólogo de Gabriela Ananias parte de uma adesão forte à matéria como ponto de partida, mas seu percurso não está preocupado com uma expressão naturalista de mundo e aproxima-se, ao final, da poesia. Isso porque a personagem inicia suas reflexões fixada à concretude do mingau, mas as sublima em uma penetração no mundo da própria literatura como elaboração de si e em uma conversa com "deus".

"deus ouve as mulheres" é um monólogo em três partes. Na primeira, a mãe fala com o filho mais velho, "gabriel", que está ali, na beira do fogão, responsável por mexer o mingau. Desligado, atento mais ao turbilhão prático da vida que às palavras da mãe, está sempre próximo de queimar a mistura. A solidão da mãe (das mães?) ganha aí seu primeiro quadro: "gabriel" está ao seu lado, mas é como se não estivesse. O diálogo não existe. Não responde, não presta atenção, não se solidariza com o discurso da progenitora, que vê na papa espécie de metáfora para sua própria vida. Como o mingau, a vida do pobre não vale nada. $E$, além de barato, o mingau é frágil: queima. Depois de queimado, as crostas que grudam na panela são como as crostas que se amontoam nos cantos da existência de cada um: enfiadas nas quinas e desvãos, não saem com lavada simples; ao falar com o filho (conosco), a personagem como que esfrega a si própria, numa luta para 
que não passe do ponto do mesmo modo que o marido morto. Assim, expõe paulatinamente seus medos, mais agudos na medida em que revela consciência de sua própria condição. Sabe que nunca faltou com seu dever e que mulher trabalha desse modo, escondida, cultivando sob a pele as doenças do cotidiano, as mesmas que corroem, mas não abatem. A raiva, no entanto, reside silenciosa no seu interior: os filhos partirão para o mundo ("ninguém nunca me disse 'saudade' além de vocês, quando querem alguma coisa de mim"), e sua condição de mulher, de vida doada ao outro, continuará lá. Ao constatá-lo, num gesto individual quase emancipatório, manda o filho para a "puta que o pariu". No entanto, recolhe-se, pede perdão, recompõe-se e liga a televisão.

Na segunda parte, embala o filho "julinho". Aqui, o diálogo se mostra ainda mais improvável: o filho adormecido, ninado no berço, mais doente que saudável, revela mais uma vez o isolamento em meio à turba da casa. No entanto, para que não morra na imponderabilidade da palavra falada, que desmanchará no ar como a canção de ninar, revela que cotidianamente registra em um caderninho os momentos vividos pelos filhos. São palavras de doação para o outro, para que saibam de sua entrega e para que tenha uma ponta de esperança de que a mutilação de seu próprio corpo não terá sido em vão. Ela pede desculpas: "julinho, eu posso escrever uma coisa no seu caderninho de quando eu crescer pra mim mesma? só uma linhazinha, eu prometo". A escrita sequer permite que elabore sobre si. Ou, ao elaborar sobre o outro, elabora sobre sua própria identidade pastosa feita de matéria alheia? De qualquer modo, o "caderninho" figura como espécie de sublimação do cotidiano, ponte para o futuro, momento em que reside a utopia de poder ser lida, de que suas palavras tenham destaque, de que finalmente seja ouvida para além do que se oculta sobre a pele ("eles só vão ler, quem sofreu porque não conseguia parar de anotar, porque não aceita esquecer, sou eu. Eu vou dar isso de presente pra eles"). A ponte com Carolina Maria de Jesus (2007) é inevitável: nos diários da catadora é como se a escrita configurasse antídoto contra os fantasmas do cotidiano de mulher pobre, com os filhos para criar. Para não cair no alcoolismo (como o sábio vizinho), ou no roubo (como as crianças da favela) ou na violência (como os homens do bairro), escreve: "prefiro escrever. Todos os dias eu escrevo. Sento no quintal e escrevo". Como Carolina Maria de Jesus, a personagem de "deus ouve as mulheres" tenta o diálogo com as amigas, também mulheres, mas estas ora desdenham dela, ora acham pretensiosa demais toda essa vida de reflexões, palavras complicadas, diários, caderninhos... Para essas "estranhas", deslocadas da identificação imediata com o mundo em que vivem, resta a escrita. Afinal, para a personagem de Gabriela Ananias, o remédio é o mesmo da protagonista de Quarto de despejo: "gosto de anotar. [...] se você tirar meu filho das doenças, anoto todas as histórias que você sabe".

Por fim, a personagem à margem da vida da casa (entre o filho absorto pela TV e o filho adormecido) fala com "deus". Mas o "deus" aqui não é a entidade impenetrável, soberana, da tradição protestante ou ortodoxa. "deus" aqui é íntimo, "menino que quer ouvir histórias", é "meu deusinho". É o "deus" que Sérgio Buarque de Hollanda (1997) habilmente mapeara na tradição latino-americana: aquele com quem se conversa, se negocia, e a quem até se chantageia. Mas se aqui ele figura como ingrediente que suaviza as dores da personagem em um diálogo lírico, é também o auge da autoconsciência solitária de mulher. A angústia é explícita, e por isso tenta seu último golpe: "o que você quis me botando aqui, hein? [...] você não sabe, né? Ou tanto faz pra você?". Mas não haverá resposta, porque "deus", como a leitura de seus caderninhos, é só promessa de futuro, mais querida que provável. Restará o silêncio - ou o esquecimento.

A sensação é de solidão progressiva a cada novo quadro e a cada tentativa de diálogo. Não é metáfora, é fotografia da condição da mulher pobre (negra?) na sociedade brasileira. Dividida entre o trabalho fora, o trabalho doméstico, o cuidado, as ameaças da doença, os sonhos não 
realizados e os prazeres podados, a personagem ainda é capaz do amor final com que termina o monólogo-carta-depoimento: "com carinho, sua mãe". Mas, se está aí a força da escrita de Gabriela Ananias, está aí também seu vício: o retrato acachapante carece de nuances. Ora, não será o leitor-espectador capaz de com poucos gestos captar a força dessa condição, ou mesmo voltar-se para ela sem precisar lidar com uma personagem que não enxerga a vida além da miséria e do medo do esquecimento? É como se dentro do universo da personagem não vislumbrássemos nenhum momento possível de protagonismo de si, de válvula de escape para desejos, sonhos ou rompimento de lógicas. Somam-se a isso certas divagações que, se são plenamente possíveis para uma dona de casa que põe sua vida em xeque, por vezes oscilam entre o verossímil e o artificial: ora há muita matéria onde é preciso refletir, ora há muita filosofia onde é preciso haver matéria. Na tentativa de reiterar as misérias da personagem, a autora insiste em imagens que se esvaziam pela repetição (o mingau é bastante produtivo de início, mas logo morre enquanto fio condutor; ou a "Índia" que diz não saber onde ficar, mas que relembra insistentemente a ponto de soar inverossímil como ponto de fuga). Assim, por vezes temos a sensação de que, para que o quadro fique claro, a autora exagera no didatismo ("não sei se é justo, gabriel, você acha? as mulheres assim só atrás da pele", "às vezes foi a última moeda do troco de ontem que a gente gastou no leite", "mulher não pode ter essa doença, não..."). Mas esses são, como se vê, detalhes de uma forma que é buscada com afinco pela autora e por isso aflora cheia de tensões. Se o monólogo ainda não se constrói tipicamente como tal (é relato, carta, conto, poema declamado?), e se na tentativa de construir imagens o texto se perde em pistas falsas, a força motriz de sua escrita é altamente produtiva: está presa à matéria, à experiência, à política do nosso tempo. Tem força. Não se sai de seu texto como se entrou. Nos dias de hoje, isso não é pouca coisa.

$$
* * *
$$

O conto "Marcas de passagem", de Matheus Gabriel de Castro Freire Oliveira, partilha desse mesmo universo tão violentamente esquecido quanto mais se revela palco de vívidas tensões: o interior da casa e a solidão das chefes de família. O autor cria uma espécie de mosaico, no qual se encaixam os perfis de quatro mulheres: a filha, Lurdinha, que sai apressada para a primeira entrevista de emprego do ano; a mãe, Eulália; a avó, Maria Tereza; e a filha de Lurdinha, Aninha. Mas se a primeira abre a história com seu passo apressado, sua passagem é apenas mote para apresentação de sua mãe. Rapidamente traçamos o perfil de Eulália: apertada com as contas da casa, preocupada com o destino da filha, o da própria mãe idosa e o da neta danada, é moldada pelas pressões do zelo e das responsabilidades de mulher do lar, de personalidade acachapada e sem horizontes largos. E antes que tenhamos acesso a qualquer outra nuance, cede espaço para a emergência daquelas que configuram o núcleo da narrativa: dona Maria Tereza e sua bisneta, Ana. A garotinha tem o perfil traçado desde o nascimento: prematura, mas saudável, é o símbolo da vivacidade e da eletricidade. Já a bisavó é construída como o oposto: em fim de vida, mal abre os olhos, e qualquer esforço é fonte inominável de dor.

O conflito começa no momento em que esses dois polos dividem sozinhos o mesmo espaço. Após saída apressada para uma consulta, Eulália deixa a bisavó e a bisneta em casa. A tensão de Maria Tereza emerge quando percebe que as horas com a menina exigiram não só atenção, mas esforço físico. Quando seu corpo pede o movimento de retorno ao casulo, o da menina almeja a conquista do céu. A bisneta implora para que a bisavó brinque, pois não basta a comunicação verbal, ora sutil, ora explícita, dos adultos. Assim, tensão interior aumentada, temos uma situação às raias do insustentável. Gesto improvável, Maria Tereza risca o próprio braço, sugerindo para a neta o começo de uma brincadeira. O sinal, no entanto, funciona. A garota corre para buscar novas canetas e pinta a avó em uma deliciosa brincadeira. 
Como se vê, a trama simples aposta na possibilidade de sublimar o cotidiano. O resultado é potente: menos que conflito de gerações ou reflexão sobre vida e morte, propõe um mergulho no corpo. O diálogo baseado em palavras não é possível. Que alternativa restaria, portanto, para uma mulher no final da vida, sem força física para o contato necessário? É aí que a personagem usa o próprio corpo para um gesto derradeiro - não de ação, mas de entrega. Depois de uma vida inteira resta não a represália, a ordem hierárquica ou a palavra sábia, mas a entrega completa para uma criança. Não para fazer uma simples concessão, nem sequer para fechar um ciclo de vida, mas para redescobrir-se: "A beleza opaca das misturas delineou o rosto da velha, acariciado pelos dedinhos. Como agradecimento, as palmas de Maria tatearam sobre as mãos de Aninha, levando ao sorriso da criança [...]. Os corpos inteiros iam se descobrindo". Matheus Freire Oliveira consegue produzir uma espécie de epifania cotidiana muito simples e, ao mesmo tempo, poderosa. Aquela que recorre à descoberta do corpo, das texturas e cores em um mundo no qual explorá-los é sempre proibido ou muito perigoso. Por entrar em zona tão densa, sua narrativa corre os riscos do salto a que se propõe. Afinal, como lançar-se em queda livre na descoberta do corpo apostando em narrativa tão transparente e consciente de si? O narrador conhece os liames de cada personagem, mostra-se tão distante e analítico que retira do leitor a possibilidade da descoberta pela própria linguagem. Linguagem essa que oscila entre a apresentação direta e viva da ação e as intervenções constantes do narrador, o qual muitas vezes polui o texto e tira do leitor a liberdade imaginativa, ou a possibilidade de sentir na própria pele a escrita que se desenha ("a pensão - era curta; em verdade, era engolida", "em tom de sabida das coisas... E sabia.", "hábito de gente responsável que era: ato burocrático"). Isso faz com que a simplicidade do cotidiano dessas mulheres conflite com interpretações de uma voz externa que em diversos momentos reboa no clichê quase ousado: "Gargalhadinhas, as duas", "E eram, as duas: vida e morte, lado a lado, como amigas. Há dia que se vai, assim, encantado". E, por vezes, como que mais preocupado com o jogo linguístico que com a trama, ignora que, afora a tensão entre bisavó e filha, as duas personagens que abrem a narrativa (e dela tomam conta em toda primeira metade do conto) figuram apenas como perfis de abertura, desamarrados, sem nenhuma função dentro do enredo que não a de preparar a entrada das demais.

De qualquer modo, há na ficção de Matheus Freire um frescor que só se encontra nas narrativas jovens: um anseio pelas situações excepcionais, vivas, que recusam a ação espetacular, mas desejam o toque profundo. E se ela tropeça ainda na forma, já se percebe ali uma rítmica e uma atenção ao detalhe que atraem. Afinal, é dos tropeços que nascem as marcas de vida e de passagem. E do risco mais profundo e duro da caneta na pele, os traços que revelarão a excepcionalidade sublime do cotidiano.

\section{Referências bibliográficas}

BERNARDET, Jean-Claude. Jean-Claude Bernardet: um crítico contra a estética da miséria. Revista Fapesp. Out. 2014. Disponivel em: http://revistapesquisa.fapesp.br/2014/10/og/ jean-claude-bernardet-um-critico-contra-estetica-da-miseria/. Acesso em 3 de abr. 2016.

CANETTI, Elias. A consciência das palavras. São Paulo: Companhia das Letras, 2011.

HOLLANDA, Sérgio Buarque de. Raízes do Brasil. São Paulo: Companhia das Letras, 1997.

JESUS, Carolina Maria de. Quarto de despejo: diário de uma favelada. São Paulo: Ática, 2007.

SZONDI, Peter. Teoria do drama moderno. São Paulo: Cosac\&Naify, 2001. 